\title{
TEORI DAN APLIKASI PEMIKIRAN KONTEMPORER DALAM PEMBAHARUAN HUKUM KELUARGA ISLAM
}

\author{
Jefry Tarantang \\ IAIN Palangka Raya \\ hukumtarantang@gmail.com \\ Received : \\ ; Accepted : \\ ; Published :
}

\begin{abstract}
The renewal of Islamic law has always coincided with the development and renewal of thought in the Muslim world with respect to the sacred text and discussing topics more closely related to philosophy or thought. Of the many prominent figures of Islamic law thinking are contemporary Islamic legal thought, such as Fazlur Rahman which offers specific moral and legal ideal terms in the meaning of texts and the early division of Islamic tradition, Muhammad Shahrur offers theoretical limits in the provisions of Islamic law, and Abdullah Ahmad An-Na'im who offers an alternative answer based on the theory of nasakh in melalukan reformulation of Islamic law that arises because the theories or results of traditional Islamic legal thinking is no longer relevant to the circumstances of the times. So the offer of renewal of contemporary Islamic legal methods such as Fazlur Rahman, Muhammad Shahrur, and Abdullah Ahmad An-Na'im. Contemporary thinking is applied in the Islamic law reformation method which can be used as a renewal in Islamic family law such as Rahman's double motion theory, Shahrur's boundary theory, and nasakh theory as an alternative answer by Na'im in the context of renewal of family law in accordance with the objectives of Islamic law applies in every place and time (shalih likulli zaman wal makan).
\end{abstract}

Keywords: theory and application, Islamic family law

Awal sejarah perjalanan hukum Islam1 atau fikih merupakan suatu kekuatan yang dinamis dan kreatif. Hal ini dapat dilihat dari munculnya sejumlah mazhab hukum yang memiliki corak sendiri-sendiri sesuai dengan latar belakang sosiokultural dan politik dimana mazhab hukum itu tumbuh dan berkembang. Dalam paradigma ushul fikih klasik terdapat lima prinsip yang m emungkinkan hukum Islam bisa berkembang mengikuti masa: 1) Prinsip Ijma'; 2) Prinsip Qiyas; 3) Prinsip Maslahah Mursalah; 4) Prinsip

\footnotetext{
${ }^{1}$ Konotasi-konotasi dari frasa hukum Islam sebagian merupakan produk persepsi Barat dan kini telah diperkenalkan kepada masyarakat muslim melalui makna linguistik khusus, seperti alqanun al-islami dalam bahasa Arab. Tidak ada frasa yang sesuai dengan hal tersebut dalam wacana pra-modern. Pada masa itu, dua istilah yang mengungkapkan komitmen komunitas muslim terhadap hukum Tuhan adalah fikih dan syariah. Lihat Norman Calder dalam Seyyed Hossein Nash dan Oliver Leaman (Ed), Eksiklopedi Tematis Filsafat Islam (Buku Kedua), Bandung: Mizan, 2003, h. 1305-1307.
} 
memelihara Urf'; dan 5) berubahnya hukum dengan berubahnya masa. Kelima prinsip ini dengan jelas memperlihatkan betapa fleksibelnya hukum Islam.2

Dengan Berlalunya waktu, perkembangan Hukum Islam yang dinamis dan kreatif pada masa awal kemudian menjelma kedalam bentuk mazhab-mazhab atas inisiatif beberapa ahli hukum terkenal, tetapi dengan terjadinya kristalisasi mazhab-mazhab tersebut, hak untuk berijtihad mulai dibatasi dan pada gilirannya dinyatakan tertutup. Semacam konsensus gradual yang memapankan dirinya yang kurang lebih bermakna bahwa mulai saat itu tidak seorangpun yang boleh mengklaim bahwa ia memiliki kualifikasi untuk melaksanakan ijtihad mutlak dan bahwa seluruh aktifitas dimasa mendatang tinggal menyesuaikan.3 Jadi secara teoritis, ijtihad memang tidak dinyatakan tertutup tetapi kualifikasinya yang ditempa sedemikian teknis serta dengan diidealkannya capaian-capaian masa lampau telah mengakibatkan ijtihad berada di luar jangkauan manusia.4

Menjawab tantangan modernitas adalah sebuah jargon yang tersirat dan disepakati dibalik beraneka ragamnya produk pemikiran muslim pada umumnya dan dibidang hukum pada khususnya pada dasawarsa terakhir setelah kaum muslimin teperangkap dalam kejumudan dan taqlid yang cukup lama pasca imam-imam mazhab. Pada abad ke-20, semakin banyak upaya pembaharuan pemikiran hukum Islam baik yang dilakukan oleh sarjana-sarjana muslim maupun oleh sarjana-sarjana orientalis.5

Pembaharuan hukum Islam selalu seiring dengan perkembangan dan pembaharuan pemikiran di dunia muslim yang berkenaan dengan teks suci6 dan

2Taupiq Adnan Amal, Islam dan Tantangan Modernitas, Studi atas Pemikiran Hukum Fazlur Rahman, Bandung: Mizan, 1989, h. 33-35.

${ }^{3}$ Setiap muslim pada dasarnya diharuskan untuk berijtihad pada semua bidang hukum syariah, asalkan dia mempunyai kriteria dan syarat sebagai seorang mujtahid. Para ulama membagi hukum melakukan ijtihad dengan tiga bagian, yaitu wajib 'ain, wajib kifayah, dan sunnah. Lihat Muhaimin, Kawasan dan Wawasan Studi Islam, Jakarta: Kencana, 2007, h. 179-180.

${ }^{4}$ Taupiq Adnan Amal, Islam dan Tantangan Modernitas, Studi atas Pemikiran Hukum Fazlur Rahman, Bandung: Mizan, 1989, h. 33-35.

5Yang terakhir ini banyak memberikan kontribusi dalam pengembangan kajian hukum Islam yang dilakukan oleh tokoh-tokoh seperti Goldziher, Joseph Shacht, N.J. Coulson dan lainlain. Namun kajian-kajian orientalis tidak mendapat reputasi yang baik di kalangan kaum muslimin karena berbagai alasan. Lihat Syamsul Anwar, Pengembangan Metode Penelitian Hukum Islam, dalam Mazhab Jogja: Menggagas Paradigma Ushul Fiqh kontemporer, Yogyakarta: Ar-Ruz, 2002, h. 149.

${ }^{6}$ Pembaharuan hukum Islam yang berkenaan dengan teks suci, antara lain teori "Hermeneutika Humanistik" dari pemikir Mesir, Hasan Hanafi, "Teori Batas" Muhamad Syahrur dari Syiria, "Analisis Teks" dari Nasr Hamid Abu Zayd dari Mesir, "Tafsir Tematik" Bintu asySyathi" („Aisyah binti „Abd al-Rahman) juga dari Mesir dan lain-lain. Lihat A. Khudori Sholeh (Ed), Pemikiran Islam Kontemporer, Yogyakarta: Jendela, 2003, h. 26-27. 
membahas topik-topik yang lebih berkaitan dengan filsafat atau pemikiran. Dari sekian banyak tokoh pemikiran hukum Islam yang menyita perhatian adalah pemikiran hukum Islam kontemporer, seperti Fazlur Rahman yang menawarkan istilah ideal moral dan legal spesifik dalam pemaknaan teks dan pembagian awal tradisi Islam, Muhammad Shahrur yang menawarkan teori batas dalam ketentuan hukum Islam, dan Abdullah ahmad AnNa'im yang menawarkan jawaban alternatif dengan berpijak pada teori nasakh dalam melalukan reformulasi hukum Islam yang muncul karena teori-teori atau hasil-hasil pemikiran hukum Islam tradisional tidak relevan lagi dengan keadaan zaman.

\section{METODE}

Penulisan penelitian ini menggunakan metode normatif melalui literatur kajian pustaka (library research) terhadap buku-buku yang berhubungan dengan tema penelitian yang dibuat, dan juga bersumber dari beberapa penelitian. Adapun pendekatan dalam pembahasan penelitian ini adalah pendekatan sejarah (historical approach) dan pendekatan filsafat hukum/ ushul fikih (philosophy of Islamic law approach) kemudian dianalisis secara kualitatif.

\section{A. Pergerseran Paradigmatik Metodologi Hukum Islam}

Pola pemikiran Islam yang beraneka ragam dan bercorak pembaharuan tentu juga berimplikasi pada aspek hukum Islam baik secara metodologis maupun wacana. Oleh karena itu metode pembaharuan hukum Islam bukanlah sebuah metode yang terlepas dari pembaharuan pemikiran, hal ini perlu pelacakan yang cermat karena tidak semua tokoh mempunyai perhatian yang khusus terhadap hukum Islam. Terlebih lagi jika di tarik ke dalam wilayah hukum keluarga muslim khususnya, sehingga dibutuhkan upaya penyesuaian bahkan modifikasi terhadap teori-teori pemikiran yang ditawarkan para tokoh yang berkaitan dengan hukum Islam.

Mencermati kerangka teorinya Wael B. Hallaq melalui pendekatan sejarah (historical approach) dalam pengembangan metode fikih (ushul figh) Amin Abdullah menguraikan paradigma metodik usul fiqh kedalam pradigma fikih literalistik, utilitarianistik dan liberalistik-penomenologik. Dinamakan paradigma literalistic karena dominannya pembahasan tentang teks. ArRisalah karya As-yafii dianggap buku rintisan pertama tentang usul fiqh, 
penulisannya bercorak teologis deduktif yang kemudian diikuti oleh para ahli ushul mazhab mutakallimun (Syafiiyah, Malikiyah, Hanabilah dan Mu'tazilah). Setelah lebih kurang lima abad (dari abad ke-2H-7H) baru mengalami perbaikan dengan munculnya asy-Syatibi (w.1388 M) yang menambahkan teori maqasyid syari'ah yang mengacu pada maksud Allah yang paling mendasar sebagai pembuat hukum.

Lebih lanjut enam abad kemudian sumbangan asy-Syatibi direvitalisasikan oleh para pembaharu usul fiqh di dunia modern, seperti Muhammad Abduh (w. 1905), Rasyid Ridho (w.1935), Abdul Wahab Khallaf (w.1956), Allal al-Fasi (w.1973) dan Hasan Turabi. Karena tidak menawarkan teori baru kecuali merevitalisasi prinsip maslahah yang ditawarkan asy-Syatibi melalui teori maqashid-nya itu Weil B. Hallaq mengkategorikan para pembaharu di bidang ushul dalam kelompok ini sebagai para pembaharu penganut utilitarianisme. ${ }^{7}$

Sementara itu pertanyaan tentang bagaimanakah teks suci dapat dipahami dan kemudian dijalankan dalam konteks dunia modern yang sudah barang tentu tidak lagi sama dengan konteks zaman nabi. Pernyataan semacam itu menurut sebagian pakar seperti Muhammad Iqbal, Mahmud Muhammad Taha, Abdullah Ahmad An-Naim, Muhammad Said Ashmawi, Fazlur Rahman dan Muhammad Shahrur. Sama sekali tidak dapat diselesaikan dengan berpijak pada prinsip maslahah klasik diatas. Mereka beranggapan prinsip maslahah tidak lagi memadai untuk membuat hukum Islam tetap relevan di dunia modern. Weil B. Hallaq menamakan kelompok ini dengan aliran liberalisme keagamaan karena cenderung berdiri pada paradigma yang terlepas dari pada paradigma klasik. ${ }^{8}$

\footnotetext{
${ }^{7}$ Majid Fakhry, Sejarah Filsafat Islam (A History of Islamic Philosophy), Penerjemah: R. Mulyadhi Kartanegara dan Nurcholis Madjid, Jakarta: PT. Dunia Pustaka Jaya, 1986, h. 455-457.

8Kelompok ini dalam rangka membangun metodologinya yang ingin menghubungkan antara teks suci dan realitas modern lebih berpijak pada upaya melewati makna eksplisit teks untuk menangkap jiwa dan maksud luas dari teks. Lihat Amin Abdullah, Paradigma Alternatif Pengembangan Ushul Fiqh dan Dampaknya pada Fiqh Kontemporer, dalam Mazhab Jogja: Menggagas Paradigma Ushul Fiqh Kontemporer, Yogyakarta: Ar-Ruz, 2002, h. 118-123.
} 


\section{B. Metode Pembaharuan Hukum Islam oleh Tokoh Kontemporer}

Banyak kritikan dan kajian yang menilai bahwa kontruksi bangunan ushul fikih klasik sebagai sebuah metodologi istinbat hukum sudah tidak relevan lagi. Berdasarkan pendekatan sejarah (historical approach) dan pendekatan filsafat hukum/ ushul fikih (philosophy of Islamic law approach) respon ini beragam baik dari yang hanya bersifat sebuah kritikan, tawaran alternatif sampai upaya rekontruksi dan dekontruksi terhadapnya. Berikut upaya pelacakan terhadap contoh-contoh metodologi yang ditawarkan beberapa tokoh yang terkait dengan kajian hukum Islam yang tentu saja selain mereka di bawah ini masih banyak lagi para tokoh yang juga melakukan upaya yang sama. Metode-metode ini dilacak melalui penelusuran terhadap tokoh yang di kategorikan Hallaq pada kelompok liberal.

\section{Fazlur Rahman}

Fazlur Rahman (Rahman) dilahirkan pada tahun 1919 kemudian tumbuh dan berkembang dalam latar pendidikan tradisional sebagaimana lazimnya masyarakat muslim pada saat itu di Pakisatan. Rahman mempelajari ilmu-ilmu keIslaman secara formal di madrasah. Setelah menamatkan pendidikan menengahnya dia melanjutkan studinya di departemen ketimuran Universitas Punjab. Pada tahun 1942 ia berhasil menyelesaikan pendidikan akademisnya di universitas tersebut dengan meraih gelar MA. dalam Sastra Arab. Sekalipun terdidik dalam lingkungan pendidikan Islam tradisional sikap kritis mengantarkan jati dirinya sebagai seorang pemikir yang berbeda dengan kebanyakan alumni madrasah. ${ }^{9}$ Sikap kritis yang menggambarkan ketidakpuasan terhadap sistem pendidikan tradisional terlihat dengan keputusannya melanjutkan studi ke barat, Oxford University, Inggris. Keputusannya tersebut merupakan awal sikap kontroversial Rahman. ${ }^{10}$ Meskipun melanjutkan studi ke Barat, Fazlurrahman tidak sepakat dengan teori sarjana Barat bahwa konsep

\footnotetext{
${ }^{9}$ Ghufron A. Mas"adi, Pemikiran Fazlur Rahman tentang Metodologi Pembaharuan Hukum Islam, Rajawali Press, Jakarta, 1997, h. 15-18.

${ }^{10}$ Fazlurrahman, Islam dan Modernitas: Tentang Transformasi Intelektual, Penerjemah: Ahsin Muhammad, Bandung: Pustaka, 1995, h. 142-143.
} 
sunnah Nabi merupakan kreasi kaum Muslimin belakangan. Bagi Rahman, konsep sunnah Nabi merupakan konsep yang shahih dan operatif sejak awal Islam dan tetap demikian sepanjang masa. ${ }^{11}$

Berbicara tentang alur pemikiran Rahman ada dua istilah metodik yang sering disebutkan dalam buku-bukunya yakni historico-critical method (metode kritik sejarah) dan hermeunetic method (metode hermeunetik). Kedua istilah tersebut merupakan kata kunci untuk menelusuri metode-metode dalam pemikirannya. Dalam memahami dan menafsirkan sumber utama Islam dalam hal ini alquran, Rahman menggunakan teori double movement (gerak ganda). Hubungan yang dialektis antara dua unsur yang terdapat dalam alquran yaitu wahyu ketuhanan yang suci di satu sisi dan sebagai sejarah kemanusian yang profane disisi yang lain. Dua Unsur inilah yang menjadi tema sentral metode Rahman. Permasalahannya ada pada bagaimana cara mendialogkan antara dua sisi tersebut agar nilai-nilai kewahyuan bisa selalu sejalan dengan sejarah umat manusia. ${ }^{12}$

Gerak pertama pada teori Rahman menghendaki adanya memahami makna al-Quran dalam konteks kesejarahannya baik secara spesifik dimana kejadian itu berlangsung (mikro) maupun secara global bagaimana kondisi sekitar kejadian itu pada umumnya (makro). Dari sini bisa diambil pemahaman yang utuh tentang konteks normative dan historisnya suatu ayat maka timbullah istilah legal specific (praktis temporal) dan moral ide (normatif universal).

Kemudian gerak Kedua yang dilaklukan adalah upaya untuk menerapkan prinsip dan nilai-nilai sistematik dan umum dalam konteks penafsiran pada era kontemporer yang tentunya mensyaratkan sebuah pemahaman yang kompleks terhadap suatu permasalahan. Disini terlihat keberanjakan Rahman dari metodologi ushul fiqh lama yang cenderung

\footnotetext{
${ }^{11}$ Fazlurrahman, Membuka Pintu Ijtihad, Penerjemah: Anas Mahyuddin, Bandung: Pustaka, 1984, h. 7.

${ }^{12}$ Ghufron A. Mas"adi, Pemikiran Fazlur Rahman tentang Metodologi Pembaharuan Hukum Islam, Jakarta: Rajawali Press, 1997, h. 15-18.
} 
literalistik dan menurutnya perlunya penguasaan ilmu-ilmu bantu yang bersifat kealaman maupun humaniora agar para penafsir terhindar dari pemahaman yang salah. ${ }^{13}$

Menurut Penulis sangat jelas, bahwa gagasan yang ditawarkan Fazlur Rahman bersifat paradigmatik yang berusaha menghindarkan pemahaman intelektual dari dogma dan batas batas dimensi kultural yang membelenggu.

\section{Muhammad Shahrur}

Muhammad Shahrur lahir di Damaskus, Syiria tahun 1938. Ia mulai menapaki jenjang pendidikan dasar dan menengah sebelum ia pergi ke Moskow untuk belajar ilmu tehnik (engineering) di Universitas hingga tahun 1964. Dua tahun kemudian 1968 ia melanjutkan pendidikan master dan doktornya dalam bidang mekanika tanah (soil mecanichs) dan tehnik bangunan (foundation engineering) pada Universitas College Dublin di Irlandia. Sepulang dari Irlandia ia memulai kiprah intelektualnya sebagai seorang professor tehnik di Universitas Damaskus, Syiria hingga sekarang. Sebelum masuk dalam jajaran selebritis intelektual muslim dunia berkat perhatiannya yang mendalam tentang pemikiran Islam yang dituangkan dalam karya monumentalnya al-Kitab wa al Qur'an: Qira'ah alMuasirah. $^{14}$

Karya monumental Shahrur yang telah mencuatkan namanya tersebut merupakan hasil perjalanan panjang intelektualnya sekitar 20 tahun. Pembacaan ulangnya terhadap Islam menghasilkan pemahaman dan

${ }^{13}$ Rahman telah menyadari kemungkinan bahaya subyektivitas penafsir, untuk menghindarkan atau setidaknya untuk meminimalkan bahaya subyektifitas tersebut rahman mengajukan sebuah metodologi tafsir yang terdiri dari tiga pendekatan: Pertama, pendekatan historis untuk menemukan makna teks; kedua, pendekatan kontentual untuk untuk menemukan sasaran dan tujuan yang terkadang dalam ungkapan legal spesifik dan ketiga, pendekatan latar belakang sosiologis untuk menguatkan hasil temuan penedekatan kontentual atau untuk menemukan sasaran dan tujuan yang tidak dapat diungkapkan oleh pendekatan kontentual. Lihat dalam Ghufron A. Mas"adi, Pemikiran Fazlur Rahman tentang Metodologi Pembaharuan Hukum Islam, Rajawali Press, Jakarta, 1997, h.149-151. Lihat juga dalam Amin Abdullah, Paradigma Alternatif Pengembangan Ushul Fiqh dan Dampaknya pada Fiqh Kontemporer, dalam Mazhab Jogja: Menggagas Paradigma Ushul Fiqh Kontemporer, Yogyakarta: Ar-Ruz, 2002, h. 134-135.

${ }^{14}$ M. In'am Esha, Muhammad Syahrur: Teori Batas, dalam Khudori Soleh dkk, Pemikiran Islam Kontemporer, Yogyakarta: Jendela, 2003, h. 296. 
kesan yang kuat tentang akurasi istilah-istilah yang digunakan dalam alKitab (alquran) dalam pembacaan ulangnya ini teori yang cukup terkenal yang ditawarkannya adalah teori batas (Nazariyyah al-Hudud).

Shahrur memandang adanya dua sifat pokok yang terdapat dalam alKitab yang mutlak harus dimengerti untuk memahami keistimewaan agama Islam, yakni hanifiyyah dan istiqamah. Kedua sifat ini selalu bertentangan tetapi saling melengkapi. Berdasarkan sejumlah ayat Shahrur menyimpulkan bahwa makna hanafiyah adalah penyimpangan dari sebuah garis lurus, sedangkan istiqanmah artinya sifat atau kualitas dari garis lurus itu sendiri atau yang mengikutinya. Hanifiyah adalah sifat alam yang juga terdapat dalam sifat alamiah manusia.

Shahrur berargumen dengan dalil fisikanya bahwa tidak ada benda yang gerakkannya dalam bentuk garis lurus. Seluruh benda sejak dari elektron yang paling kecil hingga galaksi yang terbesar bergerak secara hanifiyyah (tidak lurus). Oleh karena itu ketika manusia dapat mengusung sifat seperti ini maka ia akan dapat hidup harmonis dengan alam semesta. Demikian halnya kandungan hanifiyyah dalam hukum Islam yang cenderung selalu mengikuti kebutuhan sebagian anggota masyarakat dengan penyesuaian dengan tradisi masyarakat. Untuk mengontrol perubahan-perubahan ini maka adanya sebuah garis lurus istiqamah menjadi keharuasan untuk mempertahankan aturan-aturan hukum yang dalam konteks inilah teori batas diformulasikan. Garis lurus bukanlah sifat alam ia lebih merupakan karunia tuhan agar ada bersama-sama dengan hanifiyah untuk mengatur masyarakat. ${ }^{15}$

Berdasarkan kajiannya terhadap ayat-ayat hukum, Shahrur menyimpulkan adanya enam bentuk dalam teori batas. Pertama, ketentuan

\footnotetext{
15Secara umum, teori batas (Nazariyyah al-Hudud) barangkali dapat digambarkan bahwa terdapat ketentuan Tuhan yang diungkapkan dalam al-Kitab dan Sunnah yang mentapkan batas bawah yang merupakan batas minimal ayng dituntut oleh hukum dan batas atas merupakan batas maksimal bagi seluruh perbuatan manusia. Yang jika melanggar batas minimal dan maksimal tersebut dianggap perbuatan yang dilarang (haram) dengan kata lain manusia bisa melakukan gerak dinamis dalam batas-batas yang telah ditentukan. Lihat Amin Abdullah, Paradigma Alternatif Pengembangan Ushul Fiqh dan Dampaknya pada Fiqh Kontemporer, dalam Mazhab Jogja: Menggagas Paradigma Ushul Fiqh Kontemporer, Yogyakarta: Ar-Ruz, 2002, h. 136-137.
} 
hukum yang memiliki batas bawah. Ini terjadi dalam hal macam-macam perempuan yang tidak boleh dinikahi. Kedua, ketentuan hukum yang hanya memiliki batas atas. Ini terjadi pada tindak pidana pencurian. Ketiga, ketentuan hukum yang memiliki batas atas dan bawah. seperti hukum waris dan poligami. Keempat, ketentuan hukum yang mana batas bawah dan atas berada pada satu titik (garis lurus) tidak boleh lebih dan kurang. ini terjadi pada hukuman zina yaitu 100 kali jilid. Kelima, ketentuan yang memiliki batas atas dan bawah tetapi kedua batas tersebut tidak boleh disentuh. Karena dengan menyentuhnya berarti telah terjatuh pada larangan tuhan hal ini berlaku pada hubungan pergaulan antara lakilaki dan perempuan Keenam, ketentuan hukum yang memiliki batas atas dan bawah dimana batas atasnya tidak boleh dilampaui dan batas bawahnya boleh dilampaui. Batas atas terjadi pada riba dan batas bawah adalah pinjaman tanpa bunga (al-qard al-hasan). ${ }^{16}$

\section{Abdullah Ahmad An-Na'im}

Penetrasi pembaharuannya lebih ditekankan pada ranah hukum publik Islam, namun tokoh yang satu ini juga menyerukan paradigma yang sama dalam hal perubahan. Abdullah Ahmad an-Naim (an-Naim) adalah seorang aktivis HAM yang dikenal di dunia internasional. Lahir di Sudan pada 1946 dan menyelesaikan pendidikan S1 di Universitas Khartoum tiga tahun kemudian pada tahun 1973 dia mendapat gelar sekaligus LL.B., LL.M, dan M.A dari University of Cambridge, Inggris. Pada tahun 1976 mendapat gelar Ph.D. dalam bidang hukum dari University Of Edinburg Skotlandia dengan disertasi tentang perbandingan prosedur pra percobaan

16Metodologi yang digunakan syahrur adalah filsafat dengan titik berat pada filsafat materialisme. Hal ini terlihat pada pandangannya bahwa sumber pengetahuan yang hakiki adalah alam materi diluar diri manusia. Adapun pendekatan yang digunakan adalah pendekatan hermeunetik dengan penekanan pada asfek filologi dan ini tercermin jelas pada seluruh bagian pembahasannya. Adapun kerangka teoritik yang menjadi acuan Syahrur dalam memformulasikan ide-idenya dalam ajaran islam membedakan antara yang berdimensi nubuwah yang merupakan kumpulan informasi kesejarahan yang dengan itu dapt dibedakan antara benar dan salah dalam relitas empirisnya dan risalah adalah kumpulan ajaran yang wajib dipatuhi oleh manusia yang berupa ibadah, muamalah, akhlak dan hukum halal-haram. Lihat Amin Abdullah, Paradigma Alternatif Pengembangan Ushul Fiqh dan Dampaknya pada Fiqh Kontemporer, dalam Mazhab Jogja: Menggagas Paradigma Ushul Fiqh Kontemporer, Yogyakarta: Ar-Ruz, 2002, h. 136-137. 
kriminal (hukum Inggris, Skotlandia, Amerika dan Sudan). An-Naim termasuk ilmuan yang memiliki komitmen yang kuat terhadap Islam sekaligus mempunyai dedikasi yang tinggi untuk menegakkan HAM. Selain sebagai ahli hukum an-Naim juga seorang yang ahli dalam bidang hubungan Internasioanal. ${ }^{17}$

An-Naim menawarkan metodologi baru alternatif dalam menguak pandangan Islam terhadap HAM. Perhatian utamanya adalah hukum Islam kaitannya dengan isu-isu internasional modern seperti HAM, konstitusionalisme modern, dan hukum pidana modern. Menurutnya hukum Islam saat ini membutuhkan reformasi total "Dekontruksi.".

Metode pembaharuan hukum Islam Ahmad Na'im sebenarnya berangkat dari metodologi yang diintroduksi dari gurunya sendiri, Mahmoud Muhammad Thaha yakni teori evolusi yang memuat teori naskh (sebagaimana dikenal dalam ushul Fiqh) namun substansi dalam penerapannya akan berbeda. Dalam pandangan Thaha, teori Naskh lama yang menganggap bahwa ayat-ayat (juga hadis) madaniyah menghapus ayat (juga hadis) makiyah, harus dibalik, yakni ayat makiyah yang justru menghapus ayat madaniyyah. Keyakinan Thaha bahwa abad modern ini ayat-ayat makiyah justru menasakh ayat-ayat madaniyah karena ayat-ayat makiyah bersifat lebih universal dan abadi karena menganjurkan kebebasan, persamaan derajat tidak mendiskriminasi gender maupun agama dan kepercayaan.

Dari kerangka berpikir sang guru inilah $\mathrm{Na}$ 'im memformulasikan buah pikirannya terhadap isu-isu global yang jadi perhatiannya. Menurut An-Naim pilihan Thaha terhadap abad ke-20 sebagai abad yang tepat untuk pemberlakuan kembali ayat-ayat makiyah memang subjektif meski dikemukakan secara rasional. Namun, bagaimanapun menurut An-Na'im tidak memiliki alternatif ide yang lain untuk menggantikan pemikiran Thaha itu dengan kata lain, metodologi Thaha merupakan keniscayaan.

17Muhyar Fanani, Abdullah Ahmad An-Naim: Paradigma Baru Hukum Publik Islam, dalam Khudori Soleh dkk, Pemikiran Islam Kontemporer, Yogyakarta: Jendela, 2003, h. 3. 
Umat Islam dihadapkan kepada dua pilihan yan tidak relevan khususnya dalam bidang hukum publik. pertama, tetap menggunakan piranti hukum klasik dengan berbagai macam kekurangan dan kerancuan terminologisnya dan yang kedua, menggunakan hukum barat yang disebarkan melalui kolonialisme yang mau tidak mau harus diterima karena tidak ada alternatif yang memadai. ${ }^{18}$

Menurut penulis, pemikiran An-Na'im lebih diproyeksikan pada bidang hukum publik namun secara paradigmatik bisa diterapkan dalam bidang hukum privat pada umumnya dan hukum keluarga pada khususnya karena kegelisahan hukum Islam pada umumnya adalah sama yaitu bagaimana keberadaannya tetap relevan dalam perkembangan zaman. Hal ini berdasarkan pemikiran Na'im yang berpijak pada teori nasakh dalam melalukan reformulasi hukum Islam pada dasarnya muncul karena teoriteori atau hasil-hasil pemikiran hukum Islam tradisional tidak relevan lagi dengan keadaan zaman, sementara reformulasi hukum yang dilakukan oleh Na'im bertujuan untuk memberikan jawaban alternatif dalam menghadapi perkembangan situasi dan kondisi aktual. Meskipun demikian, jawabanjawaban alternatif tersebut belum mampu menjawab situasi dan kondisi aktual, sebab pemikiran Na'im masih dangat literal dan objektivistik. ${ }^{19}$

\section{Metode Pembaharuan dalam Hukum Keluarga Islam}

H. M. Tahir Azhary membedakan kelompok utilitarian dengan kelompok liberalis, dan konkuensi logisnya terhadap produk hukum. Hal tersebut dapat ditinjau dari persepsi-persepsi tentang sifat hukum Islam. Lebih lanjut menurut H. M. Tahir Azhary, sifat hukum Islam yang melekat pada dirinya sebagai sifat asli yang otomatis jika dikaitkan dengan hukum keluarga dan kewarisan, sebagai berikut:

1. Bidimensional. Artinya hukum Islam mencakup dua macam hubungan dalam makna vertikal (ibadah) dan horizontal

18Abdullah Ahmed An-Naim, Dekontruksi Syari'ah: Wacana Kebebasan Sipil, HAM dan, Hubungan Internasional, Penerjemah: Ahmad Suaedy dan Amiruddin ar-Rany, Yogyakarta: LKiS, 1990, h. 58-59.

${ }^{19}$ Moh. Dahlan, Abdullah Ahmed an-Na'im: Epistemologi Hukum Islam, Yogyakarta: Pustaka Pelajar, 2009, h. 314. 
(kemasyarakatan/muamalah) Dalam pandangan Islam eksistensi manusia tidak berdiri sendiri melainkan berkait erat dengan dimensi ketuhanan.

2. Adil. Sifat adil yang berkaitan erat dengan prisip keadilan dan persamaan hak antara siapapun. Dalam hukum keluarga Islam, suami dan istri memiliki kedudukan yang sama, karena itu tidak dibenarkan dominasi suami terhadap istri, atau sebaliknya. Dalam hukum kewarisan Islam baik pria maupun wanita, anak-anak dan dewasa, dapat menjadi ahli waris. Hukum Islam telah mengangkat kembali derajat kaum wanita yang sebelumnya tidak mungkin menjadi ahli waris, karena alasan-alasan irasional.

3. Individu dan Kemasyarakatan. Yang dilihat dari sudut hukum keluarga dan kewarisan Islam memberikan posisi kepada manusia baik sebagai perorangan maupun sebagai kelompok keluarga yang membentuk suatu masyarakat.

4. Konfrehensif. Hukum keluarga dan kewarisan Islam adalah dua sub system hukum yang merupkan bagian dari hukum Islam yang komprehnesif. Orang yang ingin menjadi ahli dalam hukum Islam tidak mungkin mengabaikan hukum keluarga dan hukum dan kewarisan Islam, yang boleh dikatakan sebagai "central core" dalam hukum Islam itu kedua macam sub sistem hukum Islam itu secara langsung mengatur hak-hak insividu agar terwujud suatu kehidupan masyarakat yang mapan sejahtera dan tentram.

5. Dinamis. Meskipun usianya sudah lebih dari empat belas abad namun baik hukum keluarga maupun kewarisan Islam tetap dinamis dalam makna pengembangan pemikiran melalui ijtihad terhadap berbagai macam permasalahan atau kasus dalam kedua macam sub sistem hukum Islam tersebut. ${ }^{20}$

Dari persepsi tentang sifat hukum Islam di atas, dapat dilihat perbedaan yang mendasar secara epistemologi antara dua corak ushul fiqh yang mewarnai dunia muslim kontemporer (utilitarianisme dan liberalisme) melalui teropong metodologi kedua varian tersebut pada poin pertama menurut utilitarianis, Tuhan sebagai sentral peradaban manusia (teocentris) manusia sepenuhnya tunduk terhadap nash-nash agama dan menurut liberalis manusia sebagai sentral peradaban manusia yang dibungkus dengan dimensi ketuhanan (antropocentris) sehingga dari pemahaman yang berbeda ini akan meruncing pada sisi sakralitas alquran.

${ }^{20}$ H. M. Tahir Azhary, Hukum Keluarga dan Kewarisan Islam Dalam Masyrakat Modern Indonesia, Mimbar Hukum No. 10, 1993, h. 25. 
Pada poin ke-2 sampai poin ke-4, titik tekannya adalah persepsi yang berbeda terhadap pemaknaan alquran. Kelompok utilitarian Menganggap alquran sebagai kalamullah yang mutlak secara lafzan wa ma' nan sedangkan menurut liberalis alquran mutlak secara ma'nan saja tidak secara lafzan karena dalam proses turunnya alquran berinteraksi dengan budaya manusia tanpa mengurangi nilai kesucian yang ada di dalam alquran itu sendiri tentunya. kelompok utilitarianis cenderung tidak punya keberanian untuk mengeksplorasi teks-teks yang dianggap suci sedangkan kelompok liberalis sebaliknya.

Pada poin ke-5 kedinamisan hukum Islam yang dilakukan kelompok utilitarian berangkat bulat dari paradigma dan metodologi lama yang dianggap telah mapan walaupun banyak kekurangan sehingga menurut kelompok liberal produk hukum yang seperti ini terasa kering dan cenderung ditinggalkan masyarakat modern yang sekarang ini tanpa alasan teologis mengingkarinya tapi secara alamiah meninggalkannya sehingga dibutuhkan perangkat metodologi baru yang dapat mengaktualisasikan nilai-nilai yang terkandung dalam hukum Islam yang universal dan hakiki.

\section{Teori dan Aplikasi Pemikiran Kontemporer dalam Pembaharuan Hukum Keluarga Islam}

Untuk memperjelas uraian di atas, maka berikut akan diuraikan sedikit contoh aplikasi metode pembaharuan hukum khususnya hukum keluarga Islam secara kontemporer. Contoh-contoh berikut diambil dari ijtihad-ijtihad para tokoh diatas dalam mengaplikasikan metode yang mereka gagas sendiri khususnya teori gerak gandanya Rahman, teori batasnya Shahrur, dan teori nasakh sebagai alternatif jawaban oleh Na'im.

\section{Teori Gerak Ganda (Double Movement) Fazlur Rahman}

Contoh sederhana dari teori gerak gandanya Rahman dalam hal hak istri untuk bercerai dalam keadaan tertentu (khulu') dalam analisisnya terhadapa ayat yang digunakan mayoritas ulama dalam peniadaan hak wanita ini adalah alquran Surah An-Nisa [4]: 3, yang menerangkan superioritas lelaki atas wanita. 
Pada gerak pertamanya, Rahman mencoba mengangkat aspek historis ayat dengan latar belakang sosial budaya yang berlaku tentang status wanita pada waktu turunnya ayat. Menurutnya masyarakat Arab ketika itu didominasi oleh kaum lelaki dan posisi kaum wanita sangat lah rendah sehingga wajar saja ketika bunyi teks alquran menyesuaikan dengan kondisi zaman dan konteks turunnya ayat dan hal ini dirasakan sangat bersifat temporal. Dengan mengambil nilai yang lebih universal dari gerak pertamanya yaitu tentang persamaan kedudukan antara laki-laki dan perempuan Rahman beranjak ke gerakan kedua, Menurut Rahman, adalah sangat pelik untuk mempertahankan keadaan berdasarkan ayat-ayat tersebut bahwa masyarakat harus tetap seperti masyarakat Arab abad ke-7 M, atau masyarakat abad pertengahan pada umumnya, dia berpandangan bahwa anggapan mayoritas ulama tentang monopoli kaum laki-laki atas hak cerai sama sekali tidak dicuatkan dari Alquran dan bahwa ketentuan mengenai hak cerai kaum wanita adalah positif. $^{21}$

Contoh kedua yaitu tentang kedudukan cucu selaku pengganti orangtuanya dalam menerima warisan dari kakeknya. Konsep hukum waris klasik samasekali tidak memeberi bagian kepada cucu yatim yang ditinggal wafat oleh kakeknya karena terhalang pamannya. Gerakan pertama Rahman dalam hal ini dengan pendekatan historisnya mengemukakan bahwa prinsip waris semacam itu besarkemungkinannya berasal dari praktek suku-suku Arab pada masa pra Islam. Dalam masyarakat kesukuan, tetua-tetua suku, atau suku itu secara keseluruhan, berkewajiban mengurus kepentingan anggota-anggota suku yang tidak mampu. Pada sistem patriarkal abad pertengahan, paman-paman berkewajiban mengurus keponakannya yang ditinggal wafat oleh ayahnya, sehingga anak yatim itu tidak memperoleh bagian warisan dari kakeknya.

Setelah mendapatkan nilai normatif universal dan temporalnya konteks ketentuan ayat diatas gerak kedua Rahman adalah

${ }^{21}$ Taufiq Adnan Amal, Islam dan Tantangan Modernitas; Studi Atas Pemikiran Hukum Fazlur Rahman, Bandung Mizan, 1992, h. 90. 
mengkontekstualkannya pada zaman kekinian. Pada zaman modern ini situasi telah jauh berbeda dan semakin akut, karena paman-paman semakin tidak menyukai tanggung jawabnya untuk mengurus keponakannya yang yatim dan terhalang oleh mereka dalam menerima waris. Berdasarkan pertimbangan ini Rahman berpendapat bahwa jika seorang kakek wafat dan hanya meninggalkan seorang anak lelaki serta seorang cucu dari anak lelaki lainnya yang telah wafat maka ia memperoleh bagian warisan yang sama dengan pamannya karena ia menempati kedudukan ayahnya saat menerima waris. $^{22}$

\section{Teori Batas Muhammad Shahrur}

Beralih pada contoh aplikasi teori batasnya Shahrur dalam bidang hukum keluarga dalam hal ini hukum kewarisan. Contoh terbaik dalam hal ini adalah firman Allah: li Adh-dhakari mithlu hazzi al-untsayayni. Kebanyakan para ahli fikih menganggap bahwa firman ini adalah batasan yang telah ditentukan dan tidak boleh keluar darinya dalam seluruh kasus yang dialami anak-anak. Konsep ini memukul rata semua kasus dan berpijak pada konsep yang lahir dari pemahaman ayat diatas "satu bagi anak laki-laki dan setengah bagi anak perempuan" Sedangkan menurut Shahrur batasan tersebut adalah batasan khusus yang hanya bisa diterapkan dalam kasus ketika jumlah perempuan dua kali lipat jumlah laki-laki.

Mengenai kewarisan anak ini lebih jauh Shahrur merumuskan teori batasnya berangkat dari Alquran Surah An-Nisa [4]: 11 kemudian Shahrur memberikan rumusan batas dimana setiap konteks hubungan antara anak laki-laki dan perempuan bisa saja berubah sesuai dengan jumlah perbandingan anak, dan tidak melulu terpaku pada konsep "satu bagi anak laki-laki dan setengah bagi anak perempuan" sebagaimana yang digeneralkan mayoritas ulama fiqh. Adapun formulasi teori batasnya adalah sebagai berikut:

\footnotetext{
${ }^{22}$ Ibid., h. 90-91.
} 
a. Batas pertama: li Adh-dhakari mithlu hazzi al-untsayayni (laki-laki=1: Perempuan=1/2). Ini adalah batasan hukum yang membatasi jatah-jatah atau bagian-bagiana (huzuz) bagi anak-anak si mayit jika mereka terdiri dari seorang laki-laki dan dua anak perempuan. Pada saat yang bersamaan ini merupakan kriteria yang bisa diterapkan pada semua kasus dimana jumlah perempuan dua kali lipat jumlah laki-laki.

b. Batas kedua: fa ini kunna nisa'an fawqa ithnatayni ( $\mathrm{Lk}=1 / 3$ : $\operatorname{Pr}=2 / 3)$. Batas hukum ini membatasi seorang laki-laki dan tiga perempuan dan selebihnya (lebih dari dua). Satu orang laki-laki+perempuan lebih dari dua, maka bagi laki-laki adalah 1/3 dan bagi pihak perempuan adalah 2/3 berapapun jumlah mereka (diatas dua). Batasan ini berlaku pada seluruh kondisi ketika jumlah perempuan lebih dari dua kali jumlah laki-laki.

c. Batas ketiga: wa in kanat wahidatan fa laha an-nisfu ( $\mathrm{Lk}=1$ : $\operatorname{Pr}=1)$. Batas hukum ketiga ini membatasi jatah warisan anak-anak dalam kondisi ketika jumlah pihak laki-laki sama dengan jumlah pihak perempuan, jadi masing masing anak mendapatkan separuh dari harta peninggalan.

Menurut Shahrur, jika diperhatikan pihak laki-laki pada batas kedua yang termasuk dalam kategori rumus ini tidak mengambil bagiannya berdasarkan ketentuan batas yang pertama. Pada dasarnya pembagian ini sangat alami, karena hukum batasan pertama hanya dapat diberlakukan pada kasus yang telah ditetapkan Allah dan tidak dapat diterapkan pada kasus lainnya. ${ }^{23}$

\section{Teori Nasakh (Jawaban Alternatif) Abdullah Ahmad An-Na'im}

Aplikasi teori nasakh Na'im pada bahasan hukum keluarga Islam, dapat dicermati melalui pemikiran para ulama tradisional merumuskan ketentuan hukum yang menempatkann laki-laki sebagai pemimpinpemimpin rumah tangga, sedangkan istri sebagai orang yang dipimpin.

${ }^{23}$ Muhammad Shahrur, Metodologi Fiqih Islam Kontemporer, Penerjemah: Shahiron Syamsuddin, Yogyakarta: eLSAQ Press, 2004, h. 360-361. 
Karenanya, istri harus mentaati suaminya selama tidak melanggar ketentuan hukum Islam atau perintah Allah. Rumusan ketentuan ini memiliki implikasi sebagai berikut:

a. Laki-laki bisa menikahi hingga empat perempuan dalam waktu bersamaan, sedangkan perempuan hanya bisa menikahi satu orang lakilaki dalam waktu yang bersamaan.

b. Seorang laki-laki bisa menceraikan istrinya, atau seorang dari istriistrinya dengan meinggalkan begitu saja tanpa akad atau talak dan tanpa berkewajiban memberikan alasan dan pembenaran tindakannya terhadap lembaga yang memiliki otoritas. Sebaliknya, seorang perempuan dapat bercerai hanya dengan kerelaan suami atau dengan surat keputusan pengadilan yang mengizinkannya dengan dasar-dasar khusus seperti ketidakmampuan suami atau keengganannya untuk mengurus istri.

c. Dalam pembagian waris seorang perempuan menadapat bagian setengah dari laki-laki ketika keduanya berada pada posisi yang sama dalam hubungannya dengan seorang yang meninggal. ${ }^{24}$

Menurut $\mathrm{Na}$ 'im, kepemimpinan rumah tangga dalam hukum Islam perlu dilakukan perubahan untuk menjawab situasi dan kondisi saat ini. Sebab, kepemimpinan yang paternalistik dalam kehidupan rumah tangga lebih merupakan respon aktual hukum Islam dalam menjawab kenyataan abad ketujuh daripada respon ideal hukum Islam, sehingga situasi dan kondisi saat ini juga membutuhkan rumusan-rumusan peraturan hukum yang memiliki semngat kekinian dan aplikatif di masa kini. Rumusan peraturan hukum keluarga di masa kini tidak harus sama dengan rumusan peraturan hukum Islam di masa silam. ${ }^{25}$ Adapun peraturan hukum Islam yang memiliki semangat kekinian dalam hukum keluarga adalah sebagai berikut:

\footnotetext{
${ }^{24}$ Moh. Dahlan, Abdullah Ahmed an-Na'im: E pistemologi Hukum I slam, Yogyakarta: Pustaka Pelajar, 2009, h. 238-239.

${ }^{25}$ Ibid., h. 239-240.
} 
a. Perlunya keterbukaan dan kesetaraan dalam kepemimpinan rumah tangga, sehingga kepemimpinan yang diperlukan sebenarnya bukan monopolipihak laki-laki atau suami saja, tetapi kepemimpinan kolektif yang mencerminkan kerjasama dan kebersamaan dalam menentukan sikap dan mengatur kehidupan rumah tangga. Ini berarti bahwa mereka berdua tidak perlu saling menjatuhkan atau mengalahkan, tetapi saling melengkapi.

b. Dalam persoalan perceraian, laki-laki atau perempuan harus melakukannya sesuai prosedur hukum formal di pengadilan, sehingga perceraian itu harus memiliki argumentasi rasional dan dilakukan di muka pengadilan.

c. Dalam pembagian waris, seorang perempuan harus memiliki bagian yang sama dari bagian laki-laki ketika keduanya berada pada posisi yang sama dalam hubungannya dengan seorang yang meninggal. ${ }^{26}$

\section{KESIMPULAN}

Pergeseran paradigmatik metodologi hukum Islam dilakukan oleh para tokoh berimplikasi pada aspek hukum Islam baik secara metodologis maupun wacana. Oleh karena itu metode pembaharuan hukum Islam bukanlah sebuah metode yang terlepas dari pembaharuan pemikiran yang beranjak dari teks suci dapat dipahami dan kemudian dijalankan dalam konteks dunia modern yang sudah barang tentu tidak lagi sama dengan konteks zaman nabi. Sehingga muncul tawaran pembaharuan metode hukum Islam kontemporer diantaranya Fazlur Rahman, Muhammad Shahrur, dan Abdullah Ahmad AnNa'im. Pemikiran kontemporer tersebut diaplikasikan dalam metode pembaharuan hukum Islam yang dapat dijadikan sebagai pembaharuan dalam hukum keluarga Islam seperti teori gerak gandanya Rahman, teori batasnya Shahrur, dan teori nasakh sebagai alternatif jawaban oleh Na'im dalam konteks pembaharuan hukum keluarga yang sesuai dengan tujuan hukum Islam yang berlaku di setiap tempat dan waktu (shalih likulli zaman wal makan).

\footnotetext{
${ }^{26}$ Ibid., h. 240.
} 


\section{DAFTAR PUSTAKA}

Abdullah, Amin, Paradigma Alternatif Pengembangan Ushul Fiqh dan Dampaknya pada Fiqh Kontemporer, dalam Mazhab Jogja: Menggagas Paradigma Ushul Fiqh Kontemporer, Yogyakarta: Ar-Ruz, 2002.

Amal, Taupiq Adnan, Islam dan Tantangan Modernitas, Studi atas Pemikiran Hukum Fazlur Rahman, Bandung: Mizan, 1989.

An-Naim, Abdullah Ahmed, Dekontruksi Syari'ah: Wacana Kebebasan Sipil, HAM dan, Hubungan Internasional, Penerjemah: Ahmad Suaedy dan Amiruddin ar-Rany, Yogyakarta: LKiS, 1990.

Anwar, Syamsul, Pengembangan Metode Penelitian Hukum Islam, dalam Mazhab Jogja: Menggagas Paradigma Ushul Fiqh kontemporer, Yogyakarta: Ar-Ruz, 2002.

Azhary, H. M. Tahir, Hukum Keluarga dan Kewarisan Islam Dalam Masyrakat Modern Indonesia, Mimbar Hukum No. 10, 1993.

Dahlan, Moh., Abdullah Ahmed an-Na'im: Epistemologi Hukum Islam, Yogyakarta: Pustaka Pelajar, 2009.

Esha, M. In'am, Muhammad Syahrur: Teori Batas, dalam Khudori Soleh dkk, Pemikiran Islam Kontemporer, Yogyakarta: Jendela, 2003.

Fakhry, Majid, Sejarah Filsafat Islam (A History of Islamic Philosophy), Penerjemah: R. Mulyadhi Kartanegara dan Nurcholis Madjid, Jakarta: PT. Dunia Pustaka Jaya, 1986.

Fanani, Muhyar, Abdullah Ahmad An-Naim: Paradigma Baru Hukum Publik Islam, dalam Khudori Soleh dkk, Pemikiran Islam Kontemporer, Yogyakarta: Jendela, 2003.

Fazlurrahman, Islam dan Modernitas: Tentang Transformasi Intelektual, Penerjemah: Ahsin Muhammad, Bandung: Pustaka, 1995.

Fazlurrahman, Membuka Pintu Ijtihad, Penerjemah: Anas Mahyuddin, Bandung: Pustaka, 1984.

Mas'adi, Ghufron A., Pemikiran Fazlur Rahman tentang Metodologi Pembaharuan Hukum Islam, Jakarta: Rajawali Press, 1997.

Muhaimin, Kawasan dan Wawasan Studi Islam, Jakarta: Kencana, 2007.

Nash, Seyyed Hossein dan Oliver Leaman (Ed), Eksiklopedi Tematis Filsafat Islam 
(Buku Kedua), Bandung: Mizan, 2003.

Shahrur, Muhammad, Metodologi Fiqih Islam Kontemporer, Penerjemah: Shahiron Syamsuddin, Yogyakarta: eLSAQ Press, 2004.

Sholeh, A. Khudori (Ed), Pemikiran Islam Kontemporer, Yogyakarta: Jendela, 2003. 